\title{
Scientific Work of Pre-Service Science Teacher in Basic Physics Practicum: Analysis of Major Background with Scientific Work Capabilities
}

\author{
Faiq Makhdum Noor ${ }^{1 *}$, Henry Setya Budhi' ${ }^{2}$, Dody Rahayu Prasetyo ${ }^{3}$ \\ ${ }^{1,2,3}$ Institut Agama Islam Negeri Kudus, Jl. Conge Ngembalrejo PO BOX 51, Kudus, \\ Indonesia \\ *Correspondence: faiq@iainkudus.ac.id
}

\begin{tabular}{ll}
\hline Keywords: & Abstract \\
Scientific work & Basic Physics Practicum is a course taken by the pre-service science teacher of \\
Science students & Tarbiyah Faculty of IAIN Kudus. Pre-service science teachers are required to carry out \\
Basic Physics & scientific work in the practicum. Scientific work includes scientific attitudes, scientific \\
Practicum & communication, and scientific process skills. The problem in this research is how the \\
& level of scientific work of pre-service science teachers who have different fields of \\
& study background in high school. The purpose of this study is to determine the level of \\
& scientific work of pre-service science teachers who have different fields of study \\
& background in high school. The research method used is a quantitative descriptive \\
& method in which research data are obtained through instruments in the form of \\
& questionnaire sheets and observation sheets. Based on the results of the study note that \\
the ability to work scientifically which includes scientific attitudes, scientific \\
communication, and scientific process skills possessed by a pre-service science \\
teacherwith non-natural science backgrounds is lower than with the natural science \\
ones. These results provide input to the lecturer team to revise the practicum draft that \\
has been prepared so that it is more effective in improving the scientific workability, \\
especially for pre-service science teachers with non-natural backgrounds.
\end{tabular}

To cite this article:

Noor, F.M., Budhi, H.S, Prasetyo, D.R. (2020). Scientific Work of Pre-Service Science Teacher in Basic Physics Practicum: Analysis of Major Background with Scientific Work Capabilities. Thabiea: Journal of Natural Science Teaching, 3(1), 51-58.

\section{Introduction}

Scientific work includes scientific attitudes, scientific communication, and scientific process skills. Scientific attitude consists of 5 attitude indicators namely: curiosity, responsibility, discipline, cooperation, and free-thinking. The ability of scientific communication in terms of 5 indicators including the ability to compile reports, the ability to submit reports, the ability to discuss the results of experiments, the ability to translate experimental data, and the ability to respond to opinions. Scientific process skills include 7 indicators: problem formulation, goal formulation, procedure formulation, instrument selection, data collection, data processing, and conclusion results (Nasrodin et al., 2013).

Scientific work can be seen as a process that is closely linked to a theory or concept. Scientific work integrates science concepts into the learning process that can give students hands-on learning experience. It is also related to curriculum planning. This means that all aspects of the concept must be integrated with the scope of the learning process activities (Rustaman \& Rustaman, 2010). 
Scientific work is a basic ability that students must master in science learning activities as part of the scientific method. In essence, science is built with scientific methods in understanding and observing natural phenomena in everyday life. Research conducted by Andriana revealed that project-based learning models can be used to develop students' scientific work skills in science education courses in elementary schools (Andriana, 2012).

Research conducted by Sarwi shows that implementing a laboratory development model through open-inquiry experiments is effective for developing scientific work skills. This shows that practicum activities can facilitate teachers in developing students' scientific work skills. Practical activities can encourage the learning process to be centered on students. Practicum activities not only develop psychomotor competence, but also cognitive and affective domains (Sarwi \& Khanafiyah, 2010)

The first aspect of scientific work is the scientific attitude. The scientific attitude is the disposition of thinking. Scientific attitudes become trends in research that are integrated in higher-order thinking skills such as critical thinking, creativity, metacognition, problemsolving and decision making. These thinking skills largely determine the individual quality of students. Characteristics in the realm of scientific attitudes include attitudes, interests, selfconcept, values, and morals (Hunaepi, 2017).

Some factors can influence students, including internal and external factors. Internal factors are factors within students such as initial abilities, prerequisite knowledge, activities, creativity, scientific attitudes, intelligence, learning styles, social interactions, talents, and analytical skills. The aspects of scientific attitude consist of a curious attitude, a critical attitude, an objective attitude, an attitude of respect for the work of others, a diligent attitude, and an open attitude (Yuliani \& Sunarno, 2012).

Research on the assessment of scientific attitudes from practicum activities has also been carried out beforehand but in the field of Biology. Research conducted by Zulyetti shows that general Biology practicum activities based on guided inquiry approaches can improve scientific attitudes and student motivation in carrying out general Biology practicum activities. Scientific attitude is important to be developed because it becomes support in sciencethinking skills (Zulyetti, 2017).

The second aspect of scientific work is scientific communication. Communicating scientifically is a way for students to communicate scientific knowledge from their findings and studies with the scientific community. Mastering scientific skills are very important to students so that they can convey their thoughts appropriately. Scientific communication skills can be done in the form of writing, graphics, or pictures (Nurhayati et al., 2012).

Scholarly or scientific communication is often associated with research activities, especially in the academic environment. Scientific communication becomes important and urgent to be disseminated. A researcher will always produce writings, articles, monographs, research results, ideas, ideas, inventions, and theories that are then disseminated and communicated in various forms of media (Kurniawan, 2011).

Written communication skills in preparing practicum reports are one of the main skills students must possess. Based on research from Wulandari mentioned that students already have a good ability to communicate scientifically, especially in preparing practical reports. The obstacle faced by students in preparing practicum reports is because the teacher has never asked students to prepare practical work reports (Wulandari, 2013). 
The third aspect of scientific work is the science process skills. The science process skill approach has an important role in learning activities for learning success. Students need to be guided and trained in science process skills because it will be very useful not only for building knowledge but also useful in everyday life. Thus students are trained to think logically in solving each problem (Lestari \& Diana, 2018).

The teacher is the guide for the students. Teachers must be creative in applying learning approach to direct their students to play an active role and explore their own potential. Thus students are expected to be able to develop science process skills such as observing, classifying, predicting, measuring, inferring, and communicating (Juhji, 2016).

Practicum activities are basic things that must be present. Practicum activities can support an increasing understanding of physics concepts. Besides, students can be trained in the skills that underlie experiments such as skills using measuring instruments, skills in choosing appropriate measurement data collection methods, skills in processing measurement data obtained, and so on. Practicum aims as a vehicle for training, feedback, and improving student motivation (Kustijono, 2011).

Practicum is part of learning in the form of structured and scheduled activities. Practicum activities provide opportunities for students to gain tangible experience in order to increase student understanding of theory. Practicum is one of the learning strategies that attract students in developing concepts. Through the practicum, students can observe a phenomenon that occurs so that students can understand the concepts being taught (Afreni et al., 2014).

Basic Physics Practicum is a compulsory subject in the Tadris IPA Study Program at the Faculty of Tarbiyah IAIN Kudus. Lectures are carried out by fourth of semester preservice science teacher as practicians. Practicalactivities in the practicum are assisted by six assistants. The practicianshave the right to ask for help from an assistant to solve the problem if found difficulties.

UU no 20 Th 2003 explained that forms of secondary education include Senior High School (SMA), Madrasah Aliyah (MA), Vocational High School (SMK), and Vocational Aliyah Madrasah (MAK), or other forms of equivalent. The secondary school is a continuation of the elementary school. These forms of secondary schools are an extension of the forms of general secondary education and vocational secondary education (UU No $20 \mathrm{Th}$ 2003, 2003).

The pre-service science teachers who have taken part in basic physics practicum have different major backgrounds. This is one of the causes of ability differentiation in practicum activities. Although there are many factors, the major background is very influential on the ability of the pre-service science teacher to carry out practicum especially in basic physics practicum.

The results of this study are expected to provide benefits for pre-service science teachersto become accustomed to working scientifically in solving various scientific problems. In addition, the results of this study are also expected to encourage thepre-service science teacher to get used to scientific work in their educational activities. 


\section{Method}

This research was conducted at the Natural Sciences Laboratory of the Tarbiyah Faculty of IAIN Kudus. The sample of this study was 38 of pre-service science teachers of Class A Tadris IPA 2018/2019. This research uses a descriptive quantitative research design. The variables studied in this study were the scientific workability of pre-service science teachers in the Basic Physics Practicum which included 3 main aspects: 1) scientific attitude, 2) scientific communication, and 3) scientific process skills. Data on scientific attitudes were obtained through questionnaire sheets. Whereas scientific process skills and communication skills data were obtained through observation sheets. Instrument validation is done through expert validation. Data processing using percentage analysis.

\section{Results and Discussion}

The scientific attitude according to Harlen contains two definitions, there are attitudes toward science and attitude of science. Attitude toward science is about attitudes towards science, while the attitude of science is about attitudes that are inherent after studying science. Someone has a certain attitude, it will tend to behave consistently in each circumstance. The level of scientific attitude of students can be seen from curiosity, critical of an issue, honest, trying to understand the material, accepting the opinions of others, and evaluating their own performance (Anwar, 2009).

Measurement of scientific attitudes is based on attitude grouping which can be used as indicators of scientific attitudes so that it can be easier to develop scientific attitude instrument items. Scientific attitude consists of 5 indicators including curiosity, responsibility, discipline, cooperation, and free-thinking.

The results of the percentage of scientific attitudes from the pre-service science teacher with a background in natural sciences and non-natural sciences are shown in Figure 1 as follows.
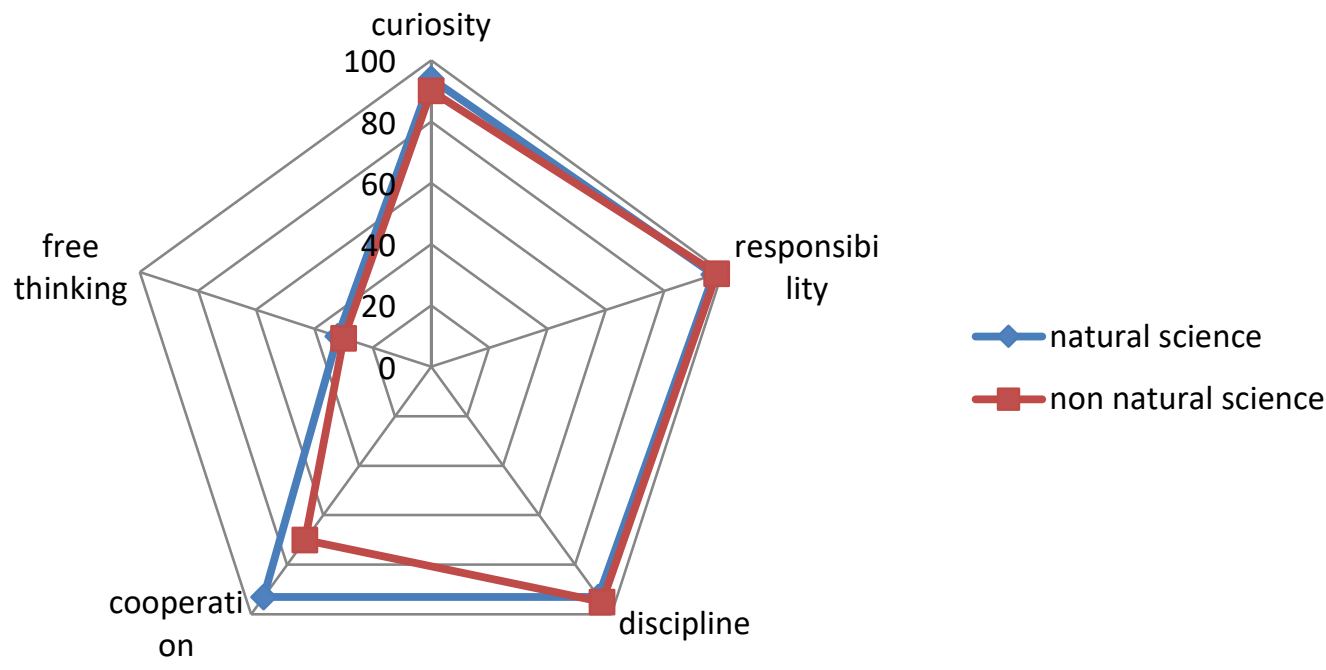

Figure 1. Percentage of Scientific Attitudes

Based on the data in Figure 1, it can be seen that almost every indicator has the same relative value except for the cooperation indicators. Curiosity, responsibility, discipline, and 
free-thinking have almost the same values between pre-service science teachersas practicianswith a science background and non-science backgrounds. But only the indicator of free-thinking has a low value. This is because practiciansare still fixated on practicum manuals and directions from practicum assistants so that they do not dare to explore broader lab objectives. Based on these data it can also be seen the differences from pre-service science teachers with natural science and non-natural science background in the indicators of collaboration. The difficulty of pre-service science teachers with a non-natural science background in understanding practical work steps is a major factor in the low value of the cooperation indicators. This becomes the correction for lecturers and the guideline preparation team to make the guidelines more detailed and easily understood by a pre-service science teacher.

Besides scientific attitude, another aspect measured in scientific work is the ability of scientific communication of pre-service science teachers. Scientific communication has an important role in conveying ideas, opinions, results, conclusions, and recommendations from information sources to recipients. This communication ability is needed by pre-service science teachers. The government has also included communication competencies as one of the graduates' competency standards. One of the competencies in the 2013 Curriculum based on Permendikbud No. 22 on content standards is "Communicating observations and experiments verbally through various media and in writing in the form of reports using correct writing conventions". Therefore, scientific communication skills are mandatory for students to master (Sarwanto, 2016).

The results of scientific communication percentage from pre-service science teacherswith a background in natural sciences and non-natural sciences are shown in Figure 2.

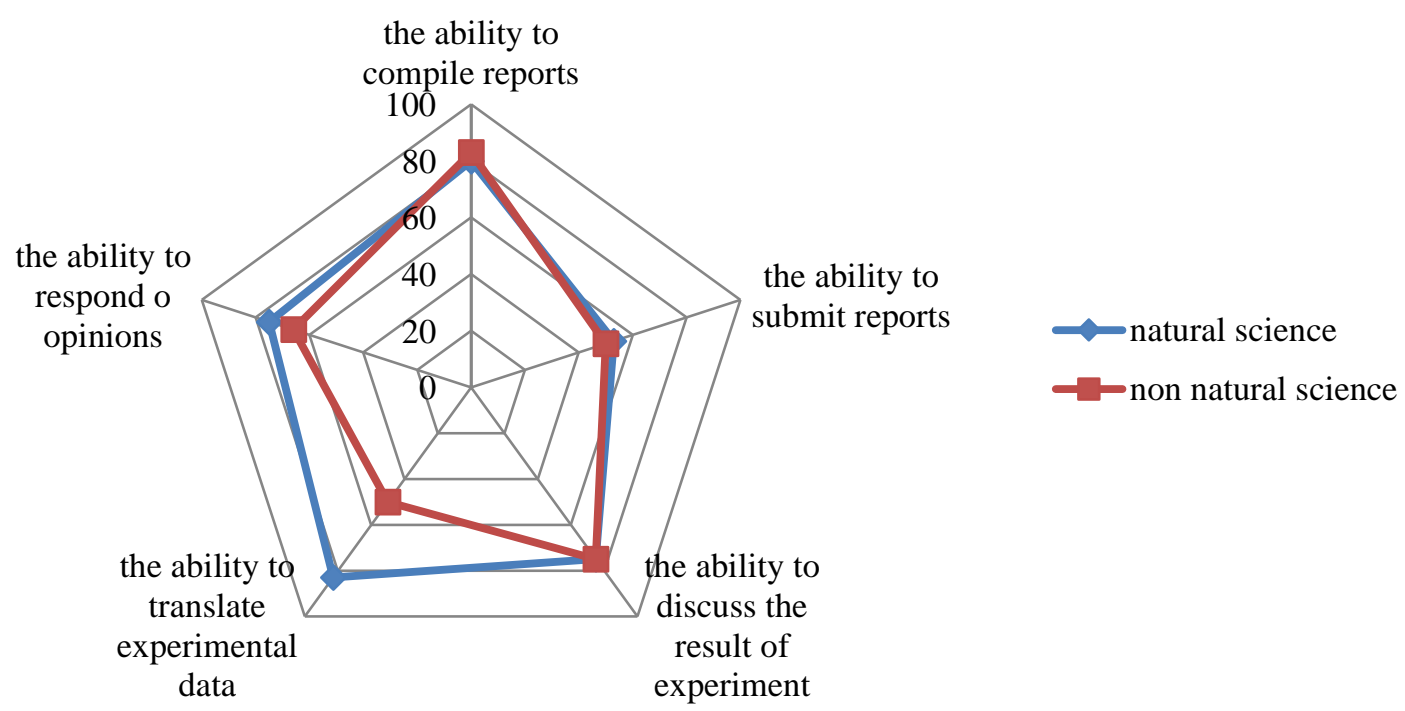

Figure 2. Percentage of Scientific Communication

Based on Figure 2, a significant difference in the scores of pre-service science teachers with a background in natural sciences and non-natural sciences is located in the indicator of translating data and responding to opinions. Pre-service science teachers from non-natural backgrounds have difficulty in understanding practicum data in the form of measured figures. Therefore, pre-service science teachers who have a non-science background tend to be 
passive in giving opinions or responding opinions in groups. This is because they have not mastered the basic concepts of physics well. The other indicators are preparing reports, submitting reports, and discussing results. These three indicators have relatively the same values between natural and non-natural pre-service science teacher backgrounds. This shows that pre-service science teachers from non-natural backgrounds are still able to compete with their friends with a natural background, although in some other indicators their scores are still lower.

The final aspect assessed in scientific work abilities is students' science process skills. Learning by paying attention to science process skills, will more make students more active. The basic science process skills include observation, classification, communication, measurement, prediction, and inference. The integrated science process skills include: determining variables, compiling data tables, compiling graphs, relating variables, processing data, analyzing investigations, compiling hypotheses, determining variables operationally, planning investigations, and conducting experiments. Through the development of science process skills, students can actively compile their own knowledge, experience the process of discovery, and construct a concept. This proves that the learning process is not only limited to the transfer of knowledge (Risamasu, 2016).

Science process skills are also called inquiry skills. Process skills help students to process new information through concrete experiences. Science process skills are very important to form concepts naturally and at the same time provide the possibility to find themselves. This can contribute to the mental development of students in exploring their own potential (Nur Aisiyah, 2017).

The results of science process skills percentage from pre-service science teachers with a background in natural sciences and non-natural sciences are shown in Figure 3.

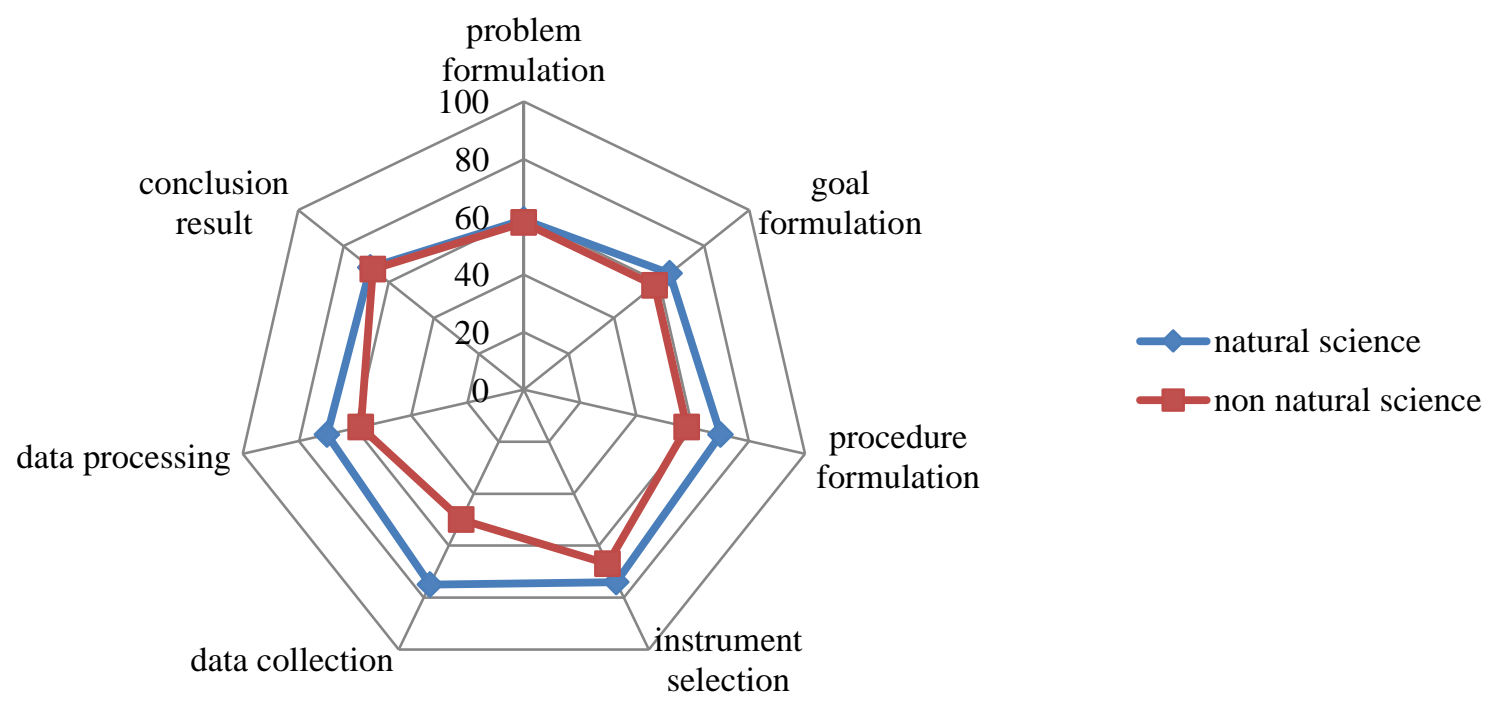

Figure 3. Percentage of Science Process Skills

Based on Figure 3, the significant difference in grades between students from the natural sciences and non-natural sciences backgrounds lies in the indicators of formulating procedures, collecting data, and processing data. For all three indicators, pre-service science teachers with a non-natural background get a lower score. It can be understood that pre- 
service science teachers from non-natural science backgrounds have basic vocational schools, so their science process skills are lower than pre-service science teachers from natural science backgrounds. As for the other indicators, namely summarizing the problem, formulating objectives, selecting instruments, and summarizing the results, have a nearly balanced value between the two.

\section{Conclusion}

The conclusion in this study is the ability of scientific work consisting of scientific attitudes, scientific communication, and scientific process skills possessed by pre-service science teachers with non-natural science backgrounds are lower than the natural science ones. This is evidenced by the ability to collaborate, translate data, respond to opinions, formulate procedures, collect data, and process data owned by non-natural pre-service science teachers who are lower than the natural science backgrounds. However, learning that emphasizes science process skills successfully makes active. These results provide input to the lecturer team to revise the design of practicum activities that have been compiled so that it is more effective in improving the ability of students to work scientifically, especially students from non-natural backgrounds.

\section{References}

Afreni, H., Sari, E. N., \& Budianingsih, R. S. (2014). Persepsi Siswa Tentang Kegiatan Praktikum Biologi Di Laboratorium Sma Negeri Se-Kota Jambi. https://media.neliti.com/media/publications/221111-persepsi-siswa-tentang-kegiatanpraktiku.pdf

Andriana, E. (2012). Analisis Kemampuan Kerja Ilmiah Mahasiswa Pendidikan Guru Sekolah Dasar Melalui Model Pembelajaran Berbasis Proyek Pada Mata Kuliah Pendidikan IPA Di SD.

Anwar, H. (2009). Penilaian Sikap llmiah Dalam Pembelajaran Sains. Jurnal Pelangi Ilmu, 2(5). http://ejurnal.ung.ac.id/index.php/JPI/article/view/593

hunaepi. (2017). Kajian Literatur Tentang Pentingnya Sikap Ilmiah. https://doi.org/10.31227/osf.io/mpueg

Juhji, J. (2016). Peningkatan Keterampilan Proses Sains Siswa Melalui Pendekatan Inkuiri Terbimbing.

Kurniawan, A. T. (2011). Konsep Komunikasi Ilmiah dalam Pemanfaatan Informasi di Perpustakaan dan Dokumentasi. 4(1), 20.

Kustijono, R. (2011). Implementasi Student Centered Learning Dalam Praktikum Fisika Dasar. Jurnal Penelitian Fisika dan Aplikasinya (JPFA), $1(2), 19$. https://doi.org/10.26740/jpfa.v1n2.p19-32

Lestari, M. Y., \& Diana, N. (2018). Keterampilan Proses Sains (KPS) Pada Pelaksanaan Praktikum Fisika Dasar I.

Nasrodin, N., Hindarto, N., \& Supeni E, S. (2013). Analisis Kebiasaan Bekerja Ilmiah Mahasiswa Fisika Pada Pembelajaran Mata Kuliah Praktikum Fisika Dasar.

Nur Aisiyah, L. (2017). Peningkatan Keterampilan Proses Sains Dasar Dengan Pendekatan Open-Inquiry. Pancaran Pendidikan, 6(1). https://doi.org/10.25037/pancaran.v6i1.2 
Nurhayati, W., Wardhayani, S., \& Ansori, I. (2012). Peningkatan Komunikasi Ilmiah Pembelajaran IPA Melalui Model Kooperatif Tipe Think Talk Write.

Risamasu, P. V. M. (2016). Peran Pendekatan Keterampilan Proses Sains Dalam Pembelajaran IPA.

Rustaman, N. Y., \& Rustaman, A. (2010). Kemampuan Kerja Ilmiah dalam Sains.

Sarwanto, S. (2016). Peran Komunikasi Ilmiah Dalam Pembelajaran IPA. https://media.neliti.com/media/publications/173508-ID-peran-komunikasi-ilmiahdalam-pembelajar.pdf

Sarwi, S., \& Khanafiyah, S. (2010). Pengembangan Keterampilan Kerja Ilmiah Mahasiswa Calon Guru Fisika Melalui Eksperimen Gelombang Open-Inquiry. 6, 8.

UU no 20 th 2003. (2003). https://kelembagaan.ristekdikti.go.id/wpcontent/uploads/2016/08/UU_no_20_th_2003.pdf

Wulandari, R. A. (2013). Analisis Keterampilan Komunikasi Dalam Penyusunan Laporan Praktikum Termokimia Pada Siswa Kelas XI IPA. 13.

Yuliani, H., \& Sunarno, W. (2012). Pembelajaran Fisika Dengan Pendekatan Keterampilan Proses Dengan Metode Eksperimen Dan Demonstrasi Ditinjau Dari Sikap Ilmiah Dan Kemampuan Analisis. 1(3), 10.

Zulyetti, D. (2017). Sikap Ilmiah dan Motivasi Belajar Mahasiswa dalam Praktikum Biologi Umum Dengan Pendekatan Inkuiri Terbimbing di STKIP Abdi Pendidikan Payakumbuh. Vol, 1, 6. 